\title{
KLUBO SĄNARIŲ PAVIRŠIŲ ATNAUJINIMO OPERACIJA: INDIKACIJOS, KONTRAINDIKACIJOS, REZULTATAI IR KOMPLIKACIJOS
}

\author{
Kipras Arcabas, Laurynas Viduolis, Alfredas Smailys \\ Lietuvos sveikatos mokslu universiteto Medicinos akademijos Medicinos fakultetas
}

Raktažodžiai: klubo sąnario endoprotezavimas, artroplastika, sąnario paviršiaus atnaujinimo operacija.

\begin{abstract}
Santrauka
Sąnarinių paviršių atnaujinimo operacijos atliekamos esant artrozès pažeistam klubo sąnariui. Ši artroplastikos procedūra skiriasi nuo ịprastinio klubo sąnario protezavimo, nes išsaugoma sąnario kaulinè struktūra ir anatomija: paliekamas šlaunikaulio kaklas, pritaikomi komponentai pagal igimtus sąnario paviršiaus diametrus, todèl nepakinta kojos ilgis ir biomechanika. Manoma, jog taip geriau atkuriama sąnario funkcija, lyginant su įprastiniu endoprotezavimu. Pacientai greitai grįžta ị aktyvią veiklą, net profesionalujji sportą. Ši pažangi operacija netapo pirmaeiliu klubo sąnario artrozès chirurginio gydymo būdu dèl ribotų indikacijų, išskirtinų komplikacijų ir pooperacinių rezultatų. Dèl operacijos technikos ir protezo savybių operacija gali komplikuotis šlaunikaulio kaklo lūžiu ar aplinkinių audinių pseudotumoru, kuris formuojasi dèl aplinkinių minkštujų audinių reakcijos į metalo jonus, susidarančius trinantis metaliniams komponentų paviršiams. Šios komplikacijos dažnesnès vyresnio amžiaus pacientams, ypač moterims. Paviršių atnaujinimo operacija indikuotina tik jauniems, aktyviems vyrams, kuriu gera kaulo kokybè. Ši operacija turi konkrečią šiandieninio chirurginio klubo sąnario artrozès gydymo poziciją.
\end{abstract}

\section{Ivadas}

Klubo sąnario kremzlès degeneracija yra vienas dažniausiai invalidizuojančių kaulų ir raumenų sistemos sutrikimų. Klubo sąnario artroplastika dèl sąnariui sugrąžinamos funkcijos ir skausmo pašalinimo tapo patikimiausia ir dažnai pacientų pageidaujama chirurgine intervencija. Ši operacija laikoma vienu sėkmingiausių ortopedijos atradimų, pripažinta XX a. pasiekimu chirurgijoje [20, 21]. Dèl plataus procedūros taikymo buvo daug dèmesio kreipiama ị operacijos techninius aspektus, protezo sudètị, formą ir mechaniką. 1990 metais buvo pasiūlyta nauja artroplastikos rūšis, naudojant paviršiaus atnaujinimo protezą. Sio protezo paskirtis
- suteikti geresnes funkcines ir revizines galimybes jauniems $(<55 \mathrm{~m}$.) pacientams. Ši problema yra aktuali, nes 12 proc. klubo sąnario artroplastikų atliekama jauniems pacientams, kuriems standartinė klubo sąnario artroplastika neužtikrina galimybès grį̌ti ị aktyvų gyvenimą. Šis protezas turèjo rečiau komplikuotis išnirimu, pasižymèti lètesniu dèvejimusi ir geresnėmis revizinėmis baigtimis, nes tai aktualu aktyviems pacientams, kurie ilgai gyvens su protezu ir pageidaus kartotinès operacijos [22]. Protezas pademonstravo puikias sąnario funkcines galimybes po operacijos jauniems vyrams ir 96,2 proc. atvejų tarnavo 11 metų [17]. Taikant šią artroplastikos techniką platesnei imčiai žmonių, buvo pastebėta, jog protezas nèra tinkamas vyresniems ( $>55 \mathrm{~m}$.) pacientams ir moterims dèl dažnų komplikacijų [3,22]. Dažniausiai revizinių operacijų prireikia dèl aseptinio komponentų išklibimo, periprostetinių lūžių ir minkštujjų audinių reakcijos ị metalo jonus, dèl kurios formuojasi pseudotumoras. Ši operacija indikuotina tik jauniems vyrams, kurie pademonstravo puikias operacijos baigtis ir sugebejjo grižti net ị profesionalujji sportą [3]. Šiame straipsnyje apžvelgiami naujausi moksliniai tyrimai ir literatūra, nagrinejjanti sąnarinių paviršių atnaujinimo operacijos indikacijas, kontraindikacijas, operacijos rezultatus ir komplikacijas.

Tyrimo tikslas - remiantis naujausios mokslinès literatūros duomenimis, išsiaiškinti sąnarinių paviršių atnaujinimo operacijai tinkamus kandidatus ir procedūros validumą, atsižvelgiant ị pooperacinius rezultatus ir komplikacijas.

\section{Tyrimo medžiaga ir metodai}

Naujausios mokslinès literatūros paieška buvo atlikta PubMed, UpToDate mokslinėse duomenų bazèse. I sisteminę apžvalgą buvo ittraukti 23 straipsniai, kuriuose aprašomos sąnarinius paviršius atnaujinančios artroplastikos indikacijos, kontraindikacijos, operacijų rezultatai ir komplikacijos.

\section{Tyrimo rezultatai}

Indikacijos. Sąnario artroplastikos tikslas yra pašalinti skausmą ir pagerinti sąnario funkciją [2]. Sąnarinių paviršių atnaujinimo operacija yra alternatyva standartinei klubo są- 
nario artroplastikai, tačiau jos nepakeičia, nes skirtingos jų indikacijos ir rekomendacijos [1,13]. Sąnarinių paviršių atnaujinimo operacijos dažniausia indikacija yra jaunų, aktyvių žmonių pažengusi klubo sąnario artrozè. Dalyje ligoninių tai vienintelè šios operacijos pasirinkimo indikacija, kadangi tik jos atveju užtikrinami kliniškai tenkinami rezultatai $[1,2,5]$. Šios operacijos tikslingumas gali būti svarstomas ir avaskulinès šlaunikaulio galvos nekrozès, juvenilinių klubo sąnario sutrikimų, uždegiminio ir potrauminio artrito atvejais $[3,4]$. Lyginant su standartine klubo sąnario artroplastika, operacija tinkama tik pacientams, kurių kaulų mineralinis tankis ir morfologija yra normali. Atnaujinant sąnarinius paviršius, sąnario anatomija nėra keičiama ar koreguojama, o sugrąžinus sąnario funkciją, kaulas turi išlaikyti apkrovas [6,22], todèl laikoma, kad ši chirurginè procedūra tinkamiausia jauniems $(<60 \mathrm{~m}$.) vyrams, kurių šlaunikaulio galvos diametras yra ne mažesnis kaip $50 \mathrm{~mm}[1,3,5,6]$.

Kontraindikacijos. Absoliučios operacijos kontraindikacijos yra tokios, kaip ir standartinès klubo artroplastikos: lokali infekcija, skeleto nebrandumas, paraplegija, kvadriplegija, negrižtamas raumenų silpnumas be skausmo [8]. Sąnarinių paviršiu atnaujinimo operacijai dar galima išskirti reliatyvias kontraindikacijas, dèl kurių dažniau prireikia revizijos [1]. Dažniausi sąnarinių paviršių atnaujinimo operacijos rizikos veiksniai yra moteriškoji lytis ir mažas šlaunikaulio galvos diametras $[3,4,12,22]$. Moteriškoji lytis gali būti siejama su mažesniu šlaunikaulio galvos diametru, o kontraindikacijos tapatinamos [9], tačiau koregavus tyrimus pagal šlaunikaulio galvos diametrą, nustatyta, jog moteriškoji lytis yra nepriklausomas rizikos veiksnys, didinantis pooperaciniu komplikacijų riziką [3]. Tai greičiausiai siejama su amžiniais hormonų pakitimais, sukeliančiais osteoporozę, kaulinio tankio pokyčiais, raiščių tamprumu ir dažnesnèmis klubo sąnario displazijomis $[7,12,15]$. Ši operacija nerekomenduojama ir pacientams su igimtomis klubo sąnario anomalijomis, osteoporoze ar kaulinèmis cistomis, dèl kurių rezultatai po operacijų būna prastesni [1,3-5,7,16,22]. Revizinių operacijų dažniau prireikia vyresniems pacientams, kuriuos operuoja mažiau patirties turintis chirurgas, kadangi protezo padetis labai svarbi, norint išvengti komplikacijų $[3,10,12,16,19]$. Vienas iš neaptartų labai svarbių veiksnių, koreliuojančiu su operacijos sẻkme, yra protezo dizainas, kadangi kai kurių gamintojų protezai parodẻ kliniškai nepriimtinus rezultatus ir buvo pašalinti iš rinkos $[4,5]$.

Operacijų rezultatai ir komplikacijos. Daug tyrimų apie pooperacinius rezultatus yra atlikę individualūs chirurgai, analizuojantys savo individualius rezultatus, todèl rezultatai skiriasi ir sunku interpretuoti operacijos patikimumą. Surinkus duomenis iš tarptautinio registro, nustatyta, jog 96,2 proc. atvejų protezas tarnauja 11 metų [18]. Praejus 10 metų, protezas pradeda tarnauti patikimiau ir už standartinę klubo sąnario artroplastiką [22]. Lyginant su standartine ar- troplastika, po paviršių atnaujinimo operacijos pacientai gali atlikti didesnès amplitudès kojos judesius, greičiau vaikščioti ir išlaikyti didesnes apkrovas [23]. Dažniausia komplikacija po klubo sąnario paviršiaus atnaujinimo operacijos (angl. Hip recurface) yra aseptinis protezo išklibimas ir periprostetinis lūžis. Pasitaiko minkštujų audinių reakcijų i metalo jonus, infekcijų, išnirimų ir idiopatinių skausmų [3,12,5]. Sąnarinių paviršių atnaujinimo operacijos pranašumas yra tas, jog pooperacinių išnirimų pasitaiko rečiau $[13,22]$, tačiau šlaunikaulio kaklo lūžis ir periprostetinis pseudotumoras yra išskirtinai šiai operacijai būdingos komplikacijos dèl išsaugomo šlaunikaulio kaklo ir metalinių komponentų trinties $[3,5,16,12]$. Nors dauguma pacientu ( 95 proc.) jaučia simptomų sumažèjimą, sąnarinių paviršių atnaujinimo operacija nèra pranašesnè už standartinę klubo artroplastiką visiems pacientams, nes revizinių operacijų prireikia anksčiau ir dažniau $[10,13,14]$. Reikia pasverti operacijos naudą ir riziką, todèl paviršių atnaujinimo operacija išlieka indikuotina jauniems vyrams su gera kaulo kokybe, o moteris dauguma centrų atsisako operuoti dèl dažnų komplikacijų $[5,7,11]$.

\section{Išvados}

1. Dažniausia sąnarinių paviršių atnaujinimo artroplastikos indikacija yra pažengusi klubo sąnario artrozè jauniems $(<55 \mathrm{~m}$.) vyrams, kurių geras kaulo mineralinis tankis.

2. Pagrindinès kontraindikacijos operacijai yra moteriškoji lytis, mažas šlaunikaulio galvos diametras $(<50 \mathrm{~mm})$ ir prasta kaulo kokybė (osteoporozè, kaulinès cistos).

3. Paviršių atnaujinmo operacijos rezultatai yra prastesni, lyginant su standartine klubo artroplastika, nes dažniau prireikia ankstyvųjų revizijų, tačiau pacientai gali tikètis geresnių funkcinių baigčių ir retesnių išnirimo komplikacijų.

\section{Literatūra}

1. Sershon R, Balkissoon R, Valle CJ. Current indications for hip resurfacing arthroplasty in 2016. Curr Rev Musculoskelet Med 2016;9(1):84-92.

https://doi.org/10.1007/s12178-016-9324-0

2. Ferguson RJ, Palmer AJ, Taylor A, Porter ML, Malchau H, GlynJones S. Hip replacement. The Lancet 2018;392(10158):16621671.

https://doi.org/10.1016/S0140-6736(18)31777-X

3. Canadian Arthroplasty Society. The Canadian Arthroplasty Society's experience with hip resurfacing arthroplasty. Bone Joint J 2013;95-B(8):1045-51.

https://doi.org/10.1302/0301-620X.95B8.31811

4. Matharu GS, McBryde CW, Pynsent WB, Pynsent PB, Treacy RB. The outcome of the Birmingham Hip Resurfacing in patients aged $<50$ years up to 14 years post-operatively. Bone Joint J 2013;95-B(9):1172-7. https://doi.org/10.1302/0301-620X.95B9.31711

5. Murray DW, Grammatopoulos G, Pandit H, Gundle R, Gill HS, McLardy-Smith P. The ten-year survival of the Birmingham hip resurfacing: an independent series. J Bone Joint Surg Br 
2012;94(9):1180-6.

https://doi.org/10.1302/0301-620X.94B9.29462

6. Ribas M, Cardenas C, Astarita E, Moya E, Bellotti V. Hip resurfacing arthroplasty: mid-term results in 486 cases and current indication in our institution. Hip Int 2014;24 Suppl 10:S19-24. https://doi.org/10.5301/hipint.5000172

7. Haughom BD, Erickson BJ, Hellman MD, Jacobs JJ. Do Complication Rates Differ by Gender After Metal-on-metal Hip Resurfacing Arthroplasty? A Systematic Review. Clin Orthop Relat Res 2015;473(8):2521-9.

https://doi.org/10.1007/s11999-015-4227-8

8. Hohler SE. Walk patients through total hip arthroplasty. Nursing 2018;48(9):24-30. https://doi.org/10.1097/01.NURSE.0000544209.08536.d1

9. Prosser GH, Yates PJ, Wood DJ, Graves SE, de Steiger RN, Miller LN. Outcome of primary resurfacing hip replacement: evaluation of risk factors for early revision. Acta Orthop 2010;81(1):66-71.

https://doi.org/10.3109/17453671003685434

10. Corten K, MacDonald SJ. Hip resurfacing data from national joint registries: what do they tell us? What do they not tell us? Clin Orthop Relat Res 2010;468(2):351-7. https://doi.org/10.1007/s11999-009-1157-3

11. Girard J. Hip Resurfacing: International Perspectives: Review Article. HSS J 2017;13(1):7-11. https://doi.org/10.1007/s11420-016-9511-y

12. Jameson SS, Baker PN, Mason J, Porter ML, Deehan DJ, Reed MR. Independent predictors of revision following metal-onmetal hip resurfacing. The Journal of Bone and Joint Surgery. British Volume, 2012;94 (6):746-754.

https://doi.org/10.1302/0301-620X.94B6.29239

13. Marshall DA, Pykerman K, Werle J, Lorenzetti D, Wasylak T, Noseworthy T, Dick DA, O'Connor G, Sundaram A, Heintzbergen S, Frank C. Hip Resurfacing versus Total Hip Arthroplasty: A Systematic Review Comparing Standardized Outcomes. Clinical Orthopaedics Related Research 2014;472(7), 2217-2230. https://doi.org/10.1007/s11999-014-3556-3

14. Gaillard-Campbell MD, Fowble C, Webb L, Gross TP. Hip resurfacing as an outpatient procedure: a comparison of overall cost and review of safety. Musculoskelet Surg 2021;105(1):111-116. https://doi.org/10.1007/s12306-020-00637-z

15. Gross TP, Liu F. Prevalence of dysplasia as the source of worse outcome in young female patients after hip resurfacing arthroplasty. Int Orthop 2012;36(1):27-34. https://doi.org/10.1007/s00264-011-1290-y

16. Daniel J, Pradhan C, Ziaee H, Pynsent PB, McMinn DJ. Results of Birmingham hip resurfacing at 12 to 15 years: a single-surgeon series. Bone Joint J 2014;96-B(10):1298-306. https://doi.org/10.1302/0301-620X.96B10.33695

17. van der Weegen W, Sijbesma T, Hoekstra HJ, Brakel K, Pilot P, Nelissen RG. Treatment of pseudotumors after metal-on-metal hip resurfacing based on magnetic resonance imaging, metal ion levels and symptoms. J Arthroplasty 2014;29(2):416-21. https://doi.org/10.1016/j.arth.2013.06.021

18. Aulakh TS, Jayasekera N, Singh R, Patel A, Roulahamin N, Kuiper JH, Richardson JB. Efficacy of hip resurfacing arthroplasty:
6 year results from an international multisurgeon prospective cohort study. Acta Orthop Belg 2015;81(2):197-208.

http://www.actaorthopaedica.be/archive/volume-81/issue-2/ original-studies/efficacy-of-hip-resurfacing-arthroplasty-6year-results-from-an-international-multisurgeon-prospecti/

19. Waters G, D'Alessandro P, Yates P. Functional navigation in hip resurfacing. ANZ J Surg 2021;91(1-2):168-173.

https://doi.org/10.1111/ans.16312

20. Moretti VM, Post ZD. Surgical Approaches for Total Hip Arthroplasty. Indian J Orthop 2017;51(4):368-376.

https://doi.org/10.4103/ortho.IJOrtho_317_16

21. Markatos K, Savvidou OD, Foteinou A, Kosmadaki S, Trikoupis I, Goumenos SD, Papagelopoulos PJ. Hallmarks in the History and Development of Total Hip Arthroplasty. Surg Innov 2020;27(6):691-694.

https://doi.org/10.1177/1553350620947209

22. Clough EJ, Clough TM. Metal on metal hip resurfacing arthroplasty: Where are we now? J Orthop 2020;23:123-127.

https://doi.org/10.1016/j.jor.2020.12.036

23. Gerhardt DM, Mors TGT, Hannink G, Van Susante JLC. Resurfacing hip arthroplasty better preserves a normal gait pattern at increasing walking speeds compared to total hip arthroplasty. Acta Orthopaedica 2019; 90(3):231-236.

https://doi.org/10.1080/17453674.2019.1594096

\section{HIP RESURFACING INDICATIONS, CONTRAINDICATIONS, RESULTS AND COMPLICATIONS}

K. Arcabas, L. Viduolis, A. Smailys

Keywords: hip replacement surgery, hip endoprosthesis, arthroplasty, hip resurfacing.

Summary

Hip resurfacing procedures are performed on patients with a hip arthrosis. This surgery differs from total hip arthroplasty, since the bone structure and anatomy of the joint are preserved: the femoral neck is left uncut, the specific components according to the congenital diameter of the joint surfaces are applied, which does not alter the length of the leg and biomechanics. It is believed that this is a better restoration of joint function compared to total hip arthroplasty. Patients quickly return to their activities, even professional sports. However, this promising procedure did not become the primary surgical treatment of hip arthrosis due to limited indications, exceptional complications and postoperative results. Due to the technique of the operation and the properties of the prosthesis, the procedure can lead to fracture of the femoral neck or pseudotumor of the surrounding tissues. The pseudotumor is formed due to the reaction of the surrounding soft tissues with metal ions, which are formed by rubbing the metal surfaces of the components. These complications are more common in elderly and female patients. As a result, hip resurfacing surgery is indicated only for young, active men with good bone quality. Thus, this operation has a specific role in today's surgical treatment of hip arthrosis.

Correspondence to: kipras.arcabas@stud.1smu.lt

Gauta 2021-10-01 